\section{Know your Japanese host}

SIR - Your feature on "Employment in Japan" (Nature 362, 867-870; 1993) did a good job in describing the opportunities available for foreign scientists to work in Japan. To be complete, however, your article should have mentioned the experiences of previous fellows so that applicants would know about potential difficulties. Having spent more than two years at a Japanese national institute, first as an AIST (Agency of Industrial Science and Technology) fellow and now as an STA (Science and Technology Agency) fellow, I've been able to see and hear about many commonly encountered problems.

You warn prospective fellows that "applicants should take care to avoid institutes best described as 'dinosaurs'." A far more important consideration is choosing the Japanese host researcher, who is the individual with whom the researcher most often comes in contact and who is responsible for the working conditions. A sour relationship with a host guarantees a miserable fellowship. Instances of Japanese hosts using their foreign researchers as laboratory technicians, or ignoring them completely, while spending the fellow's research funds, although certainly in the minority, are not uncommon. More serious situations have occurred in which the host insists on exerting undue control over a fellow's lifestyle both inside and outside the workplace. To be fair, such problems are not unique to Japan. But I would strongly advise a potential applicant to have made some face-to-face contact before making a final decision. Finding a compatible host is, I believe, the single most important factor in determining a successful fellowship.

Another complaint is the geographical isolation of Japan. Most visiting researchers come as postdoctoral fellows and this isolation acts as a barrier to finding a permanent position elsewhere. Foreign journals containing job announcements sometimes arrive after the deadline for applications. Travelling to an interview or to attend a conference is often prohibitively expensive. It is easy for a foreigner in Japan to feel out of the mainstream and to lose contact with colleagues and potential employers elsewhere.

Finally, the language barrier is formidable. It is rare that an individual arrives already fluent in Japanese. Most fellows arrive with little knowledge of Japan let alone the Japanese language. By relying only on English, the potential for misunderstandings is great. Patience and flexibility on the part of the researcher, as well as a willingness to learn the language and customs of Japan, are required. In addition, the language barrier creates an even more serious problem for the researcher's family. Opportunities for employment or socializing are limited at best and the spouse frequently complains of boredom. Even outside the workplace, the language barrier affects the researcher.

None of this should dissuade prospective fellows from coming. I believe most fellows (myself included) have found their stays to be professionally rewarding. But in order to prevent disappointment or hard feelings between future fellows and their Japanese colleagues, it is essential that foreign researchers contemplating a long-term visit to Japan should be aware of the problems that can arise.

\section{Philip A. Jarvis}

Geological Survey of Japan,

Higashi 1-1-3, Tsukuba,

Ibaraki 305, Japan

\section{Joking apart}

SIR - US readers of Nature rightly considered it scandalous when Nature recently stated $(\mathbf{3 6 3}, 480 ; 1993)$ that "the US public rightly considered it scandalous that their vice president could not spell potato and thought that Latin Americans speak Latin. . ." because, while the first really did happen, the second was only a joke by Johnny Carson on the Tonight show.

Only a scientist could confuse reality with television in a leading article about the need for factual accuracy.

\section{Michael Broyde}

Department of Religion,

Emory University,

Atlanta, Georgia 30322, USA

\section{UNESCO}

SIR - Your leading article (Nature 363, 382 ; 1993) on recent steps taken by the United States to rejoin UNESCO was disappointing. Both the United States and Britain have left the organization in protest against Dr A. Amadew-Mahtar M'Bow's policies. It would seem though, that his replacement by the distinguished Spanish biochemist Dr Federico Mayor has so far failed, despite many years of trying, to persuade the two countries to rejoin.

UNESCO's contributions to the developing countries can be largely felt and experienced by people living in these countries. I was made aware of some of UNESCO's contributions to the Middle East while holding an academic senior position in which I was responsible for research and development. Its advice, help and contribution to many cultural and scientific ventures was plain to many in the Middle East, ranging from attempts to restore and preserve ancient towns and cities to the organization of visits to places such the International Centre for Theoretical Physics in Trieste. In fact, UNESCO's contribution seemed to be complementary to the greatly appreciated works of organizations such as the British Council and the US Agency for International Development.

The United States and Britain should reconsider their position and rejoin UNESCO as soon as possible. I am sure that their contribution, at all levels, would be greatly valued. Finally it is evident that the exact changes sought by both countries can be met only by working from within and not by simply staying out.

M.S.Suleiman

University of Bristol,

Department of Physiology,

Park Row, Bristol BS1 5LS, UK

\section{Native rights}

SIR - I was annoyed to read (Nature 363, 388 ; 1993) that the government of Queensland (Australia) is considering legislation declaring "its right to a share of any financial gain made from research involving native plants and animals". Surely, the rights to native plants and animals belong to the natives?

Native people around the world have been the victims of European aggression and expansionism for centuries. The looming battle over "ownership" of native species (or more correctly, their products) could be an opportunity for the world to recognize (finally) native rights to native materials. The English-speaking invaders of Australia and North America as well as the Spanish- and Portuguese-speaking invaders of "Latin" America have stolen the land rights (mining, logging and even water) of the people who most civilized thinkers would admit are the rightful owners.

Today, once again, there are rumours of great riches in the jungles and the Biotech Conquistadors will walk all over the rights of natives in order to steal their treasures. They will enlist the knowledge of the few remaining native wise-men for clues as to exactly which species contain the prize. The invaders, well versed in the weaponry of public relations, will argue that some profits will trickle down to the poor natives or promise that the profits will be used to create nature reserves (designed, administered and enjoyed mostly by European invaders). The rights of natives will again be abused in order to enhance the wealth of the conquerors.

Jamle Love

76 Main Street,

Roslin, Midlothian EH25 9LS, UK

\section{Letters submitted for Correspondence} should be typed, double-spaced, on one side of the paper only.

NATURE • VOL 364 